\title{
Development of Multimedia Based Sport Injury Pencak Silat Management Model
}

\author{
Suriani Sari, Moch.Asmawi, James Tangkudung, Achmad Sofyan Hanif, Firmasyah Dlis
}

\begin{abstract}
Pencak silat is one of the sports that become the mainstay of the Indonesian nation in every national and international tournament. In its practice, however, foot accidents often occur. The purpose of this study was to obtain empirical data on product effectiveness as a result of developing multimedia-based martial arts injury models to increase the knowledge of trainers and athletes in handling injuries. The research method used is quantitative. As the results, each coach and athlete can understand the handling of injuries that occur so that athletes who experience injuries do not experience mismanagement which can result in recurring injuries or decreased the performance of athletes. It can be concluded that athletes or coaches can collaborate with physiotherapists in determining the exercises that are appropriate to the strand and type of injury.
\end{abstract}

Keywords: Pencak Silat, Multimedia, Model Development.

\section{INTRODUCTION}

Nowadays, sports become a necessity for most people. Sport is defined a physical activity which is very important and closely related to life (Pérez-Samaniego, Fuentes-Miguel, Pereira-García, López-Cañada, \& Devís-Devís, 2018). Martial arts are part of the body contact category which means sports between athletes they face each other directly without a barrier. Martial arts are sports involving physical contact to hit, kick, and slam (Stefani, 2019). Capacity building in the field of sports needs to be further enhanced and promoted (Edwards, 2015). Martial arts are a very popular sport because it describes a group of competitive sports from two athletes fighting each other. These martial arts vary greatly in their protective techniques, rules, and equipment and these factors affect injury and the level of injury. Pencak silat is one of the indigenous cultures of Indonesia (Kartomi, 2011). Pencak silat is a self-defense cultural heritage of the Indonesian people. Human always defend themselves from natural, animal and fellow threats which threatens their integrity. The basic concept in martial arts is attacking, wrestling, and giving up maneuvers, including strangling and locking joints, it is necessary to know, understand and manage injuries so that this sport is closely related to the risk of injury. Sports injury is defined as

\footnotetext{
Revised Manuscript Received on September 22, 2019.

Suriani Sari, Universitas Negeri Jakarta, Indonesia. surianisari@yahoo.co.id

Moch.Asmawi, Universitas Negeri Jakarta, Indonesia. asmawi.moch1@gmail.com

James Tangkudung, Universitas Negeri Jakarta, Indonesia jamestangkudung.unj@gmail.com

Achmad Sofyan Hanif, IKIP PGRI Pontianak. sofyan_dean@yahoo.com

Firmasyah Dlis, IKIP PGRI Pontianak. firmansyahdlis.unj@gmail.com
}

tissue damage during exercise both during competition, practice and after doing the sport (Corey Joseph, 2017). The risk of sports injuries is something that is very likely to happen to every athlete in doing exercises or competing (Vergeer, 2006). Doing the exercises to develop muscles in detail in exercising, too much training load can result in injury (Stares et al., 2018) (Bauer et al., 2019). Injury is a condition that results in damage to the tissue both in the bones, muscles, soft tissues, nerves and skin. The severity of the injury includes: 1) minor injury: an injury that is not followed by significant damage (Torre, Evashwick-Rogler, Nasser, \& Iatridis, 2019) to the tissue, swelling that does not affect screening such as blisters, bruises. 2) moderate injury: tissue damage, pain, real swelling, interfering with pregnancy, such as sparin, strain (Health, 2010). 3) severe injury to severe tissue damage, large stumps, pain is not restrained, unable to perform / must stop exercise (Nicola Smania, 2012). Based on observations in the field a few years ago in martial arts consisting of judo, karate, kempo, pencak silat, taekwondo, and fighting degrees, generally injuries that occur are caused by trauma, muscle weakness and flexibility. Sports injuries should be prevented because prevention is better than cure (Myrick, 2015), but if this injury occurs then the trainer must take action on the athlete so that the injured athlete can recover (Krabak, Waite, \& Lipman, 2014) quickly and play again and take part in the training program and injury does not occur over and over again. Sports injuries are defined as injuries that occur as a result of sports activities both directly and indirectly which affect the musculoskeletal system and all other systems and organs that influence it so that it affects other systems. And some multimedia-based research after testing and revision and producing multimedia products are feasible to use and can improve the quality of learning. Besides, multimedia is an efficient and attractive step for users.

\section{LITERATURE REVIEW}

Sports injuries cover all kinds of injuries both during training and during exercise (Timpka et al., 2015) (Fortington et al., 2015) (Bogardus, Martin, Richman, \& Kulas, 2019) (matches) or afterwards. Martial arts were originally developed as a self-defense (Kalina, 2015) tool that included mental and physical strength and was carried out by millions of people around the world. Multimedia can develop sensory abilities and attract interest (Molina, Navarro, Ortega, \& Lacruz, 2018) (Hartman \& Johnson, 2018) (Park, Flowerday, \& 


\section{Development of Multimedia Based Sport Injury Pencak Silat Management Model}

Brünken, 2015). This is supported by Computer Technology Research $(\mathrm{RCH})$, stating that people are only able to remember $20 \%$ of what is seen $30 \%$ of those heard. But people can remember $50 \%$ of what is seen and heard $80 \%$ of what is seen, heard and done. Sports injuries can be caused by two important factors (Raikes, Athey, Alfonso-Miller, Killgore, \& Grandner, 2019) namely internal and external factors. The internal factors are factors whose elements already exist in the athlete.

\section{Methodology/Materials}

Research and development method is a research that is used to create new products and / or develop existing products based on needs analysis in the field (observation, interviews, initial needs questionnaire). The importance of handling the right injury to the athlete for the coach is in providing the right training program in accordance with the characteristics of the injury that has occurred and does not recur or aggravate the injury and this must also be understood by the athlete him or herself and the trainer as well. The usual handling of injuries is by the PRICE method (Protection, Rest, Ice, Compression, Elevation). The PRICE method is a method of handling initial injuries and can only be done 2 X 24 hours and usually signs of inflammation in the area that has an injury which still leaves residual symptoms, so further handlers need to be used for pain, swelling, redness, heat and lesion function that has reduced or already no longer exist. The researcher modeled the development of handling injuries using multimedia in the hope that researchers continued the initial handling to be a follow-up treatment by looking at the characteristics and types of injuries that occur in martial arts and can be understood by athletes and coaches. This is because multimedia containing text, sound, images, music, and videos, makes the reader more dynamic in learning something that functions as a trigger so that the reader does not feel bored and more understanding to develop what is learned more about a topic. Factors that cause injury include: 1) Endogenous factors (from within the body itself), a) Physical condition, can be caused by disease attacks or contraindications to exercise, b) Aged which gradually decreases the ability of the body's system to function . c) Gender, the difference in weight between men and women makes the possibility of injury, e) History of previous injuries in the past provide a greater opportunity for the emergence of similar injuries at the same place on the body, f) Preparation for competition, competition is an opportunity to shows performance as a result of previous training. 2) Exogenous factors, a) Providing an unprofessional training load, such as an increase in exercise intensity, changes in sudden training methods, incorrect training techniques, b) Facilities for training, adequate facilities will reduce the possibility of injury, c) Equipment, Equipment which is not feasible to use or already uncomfortable, d) Environment, cold air with heating that is less able to reduce elasticity and lead to joint stiffness, e) Fatigue due to heat, as an injury that occurs when doing physical exercise in a hot environment. Sports injuries according to the time of occurrence are divided into two namely acute injury and chronic injury. 1) Acute injuries, injuries that occur due to sudden overload of tissue and not optimal stretching. 2) Chronic injuries Chronic injuries occur due to errors in movement or errors in training and matches, then various types of injuries, 1) Minor injuries that consist of a. Spasm, which is an unconscious contraction of the muscles continuously b. Thaigness, c. Crash is a condition in which muscles contract continuously due to activities that cause muscles to contract, d. Bruising, the condition of rupture of small blood vessels under the skin tissue due to traumatic injury without tearing the surface of the skin. e. Swelling, Swelling occurs when irritation occurs on exposed tissues which increases the reaction of the immune system and body cells, 2) Moderate injury, a. Strains consist of Level 1 (mild), Level 2 (moderate), Level 3 (severe), this stain is a pull or strain in the muscle, muscle membrane, and muscle tendon, b. The sprain consists of Level 1 (mild), Level 2 (moderate), Level 3 (severe), Level 4 (fracture sprain) which is (the anterior cruciate ligament) is a stretch or tear of the joints and ligaments. $26 \%$, the principles of initial treatment or early treatment of sports injuries include: PRICE based treatment (Protection, Rest, Ice, Compression, Elevation,), medical treatment (drugs and surgery), sports physiotherapy, sports massage.

Primary injury is direct trauma that injures the cell itself. While secondary injury is triggered by the body's response to the trauma, the method used in this study is development research that is carried out based on the development of the Borg \& Gall model.

The work in developing a model for handling injuries in martial arts is the identification of injuries that occur. Next, history is taking to make a diagnosis of the injury that occurs to determine the handling of the injury that is done. After the design of the handling model was obtained, then the injury handling modeling was carried out and documented in the form of gamar and video with probands according to the conditions per injury. The next stage includes production using the Multimedia program.

\section{RESUlts AND FINDINGS}

The results obtained during field observations in each of the martial arts branches were obtained by athletes who suffered martial arts injuries in the judo branch, the number of athletes 5 injured $2(40 \%)$, karate number 10 athletes who suffered 9 injuries $(90 \%)$, pencak silat number of athletes 26 people injured $20(76.9 \%)$, the number of athletes 8 people injured 7 (94.4\%), the number of athletes 22 who suffered injuries 16 (72.2\%), taekwondo number of athletes 14 injured person $13(92.8 \%)$.

Criteria for athletes who can exercise again are 1) recovery phase has been passed, 2) full joint movement without pain, 3) no persistent swelling, 4) sufficient strength and muscle endurance, 5) good flexibility, 6) good profrioseption , 7) sufficient cardiovascular endurance, 8) can do the necessary exercise techniques, 9) no permanent biomechanical abnormalities, 10) psychologically prepared.

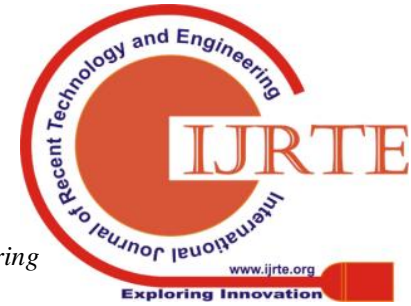


There are 9 steps that will be carried out including: Phase 1. Requirement analysis Phase 2, Product planning phase 3. Initial product development phase 4. Initial trial Phase 5. Main revision Phase, 6 product. Test main try (medium scale), Stage 7. Revision of operational products based on the results of stage 6, Stage 8. Operational trials (wide scale), Stage 9. Revised final products based on the results of stage 8.

The results of the model development carried out include; (1) presentation of overall data (needs analysis, evaluation data, and trial data), (2) effectiveness and (3) discussion.

Table 1: Range of Product Material Development of Injury Management Model in Multimedia Based Pencak Silat

$\begin{array}{llll}\text { Fase 1 } & \text { Fase 2 } & \text { Fase 3 } & \text { Fase } 4\end{array}$

1 .

tretchi

1.

1. $\mathrm{ng}$

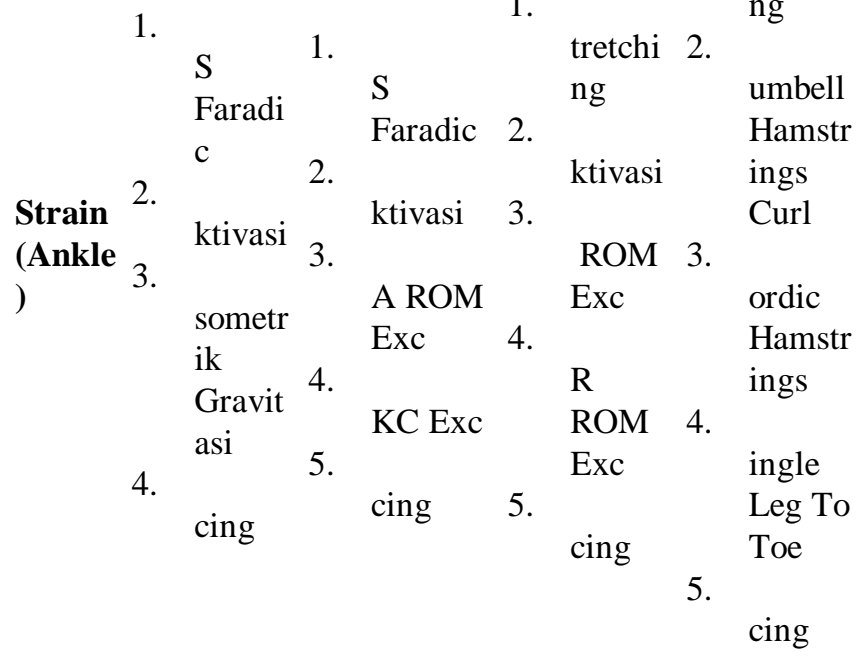

Fase $1 \quad$ Fase $2 \quad$ Fase $3 \quad$ Fase 4

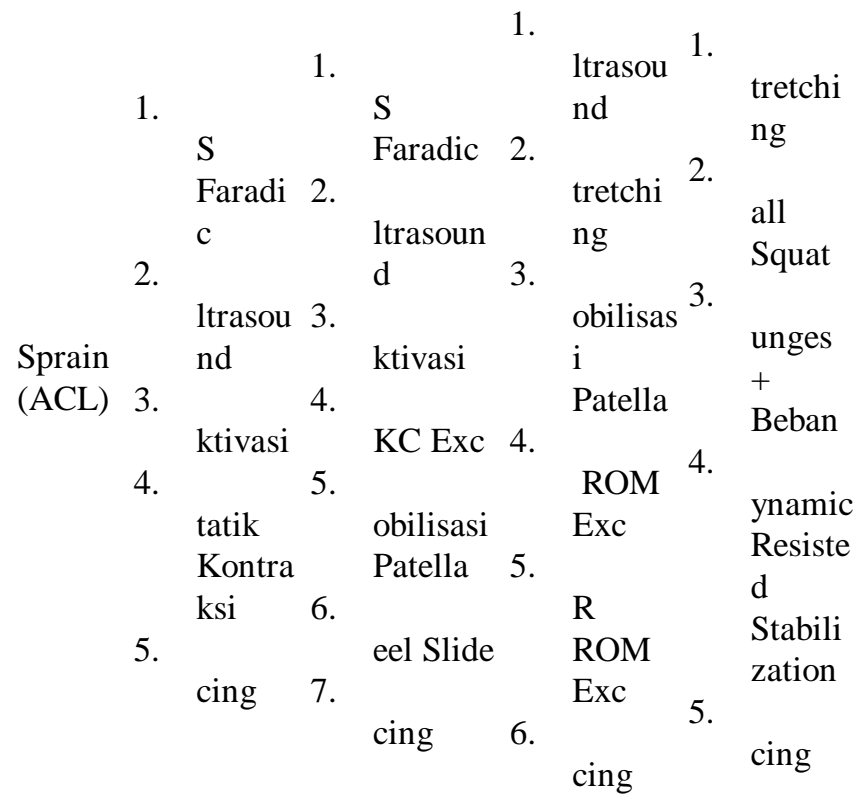

Based on tests conducted on 5 (Five) experts, the variety of models for handling multimedia-based sports injuries as a whole is feasible to use in improving the knowledge of martial arts trainers and athletes.

Table 2: Difference Test Results of Average Sample

\begin{tabular}{ll}
\hline Data Groups & $\begin{array}{l}\text { After receiving } \\
\text { Treatments }\end{array}$
\end{tabular}

Average $\pm S D$

Experimenta
l Groups
Control
groups
$19,20 \pm 1,69$
$\mathrm{P}^{*}=$ different test is using independent sample t test
From the table, it is known that the value of Sig. (2-tailed)
$0.001<0.05$. Thus, there was a significant difference in the
post-test in the treatment group given the treatment of injury
that was appropriate for the injury with the control group.
Thus, variations in the model of handling sports injuries
provide a significant increase in the functional ability of the
movement in the treatment group

\section{Conclusion}

Strain and sprain ankle are the most common injury that happen in sport, especially in pencak silat which is one of component from martial art. Those injury will lead into recurrent injury if it does'nt get a proper rehabilitation. Therefore, researcher has been design basic rehabilitation based on every phase in sport rehabilitation starting from phase 1 up to 4 , where the athletes prepared to return to sport. This multimedia method has an aim to educate and enhance the understanding of every athletes to do some basic sport rehabilitation when they are experiencing injury on their ankle.

\section{ACKNOWLEDGEMENTS:}

The researchers would like to address their gratitude to Health and Recreation Physical Education Study Program IKIP PGRI Pontianak Ristek Dikti support and finance Rescarch Doctoral Dissertation. Decree of Strengthening Research and Development Number 3/E //KPT/2018. Thanks to KONI West Borneo for providing opportunities to conduct research.

\section{REFERENCES}

[1] Bauer, P., Uebellacker, F., Mitter, B., Aigner, A. J., Hasenoehrl, T., Ristl, R., . . . Seitz, L. B. (2019). Combining higher-load and lower-load resistance training exercises: A systematic review and meta-analysis of findings from complex training studies. J Sci Med Sport. doi:10.1016/j.jsams.2019.01.006

[2] Bogardus, R. L., Martin, R. J., Richman, A. R., \& Kulas, A. S. (2019). Applying the Socio-Ecological Model to barriers to implementation of ACL injury prevention programs: A systematic review. J Sport Health Sci, 8(1), 8-16. doi:10.1016/j.jshs.2017.11.001

[3] Corey Joseph, C. F. F. (2017). Sports Injury. International Encyclopedia of Public Health.

[4] Edwards, M. B. (2015). The role of sport in community capacity building: An examination of sport for development research and practice. Sport Management Review, 18(1), 6-19. doi:10.1016/j.smr.2013.08.008

[5] Fortington, L. V., Donaldson, A., Lathlean, T., Young, W. B., Gabbe, B. J., Lloyd, D., \& Finch, C. F. (2015). When 'just doing it' is not enough: assessing the fidelity of player performance of an injury prevention exercise program. J Sci Med Sport, 18(3), 272-277. doi:10.1016/j.jsams.2014.05.001

[6] Hartman, H., \& Johnson, P. (2018). The effectiveness of multimedia for teaching drug mechanisms of action to undergraduate health students.

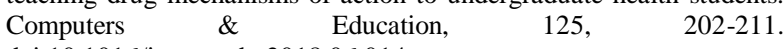
doi:10.1016/j.compedu.2018.06.014 
[7] Health, D. o. (2010). What are soft tissue injuries? Soft tissue injuries (Sprains and strains)

[8] James R. Andrews, M., Gary L. Harrelson, EdD, ATC, Kevin E. Wilk, PT, DPT. (2012). Physical Rehabilitation of the Injured Athlete 4 Edition. i-ii. doi:10.1016/b978-1-4377-2411-0.00042-3

[9] Kalina, R. M. (2015). Agonology as a Deeply Esoteric Science - An Introduction to Martial Arts Therapy on a Global Scale. Procedia Manufacturing, 3, 1195-1202. doi:10.1016/j.promfg.2015.07.198

[10] Kartomi, M. (2011). Traditional and Modern Forms ofPencak Silatin Indonesia: The Suku Mamak in Riau. Musicology Australia, 33(1), 47-68. doi:10.1080/08145857.2011.580716

[11] Krabak, B. J., Waite, B., \& Lipman, G. (2014). Evaluation and treatment of injury and illness in the ultramarathon athlete. Phys Med Rehabil Clin N Am, 25(4), 845-863. doi:10.1016/j.pmr.2014.06.006

[12] Molina, A. I., Navarro, Ó., Ortega, M., \& Lacruz, M. (2018). Evaluating multimedia learning materials in primary education using eye tracking. Computer Standards \& Interfaces, 59, 45-60. doi:10.1016/j.csi.2018.02.004

[13] Myrick, K. M. (2015). Pediatric Overuse Sports Injury and Injury Prevention. The Journal for Nurse Practitioners, 11(10), 1023-1031. doi:10.1016/j.nurpra.2015.08.028

[14] Nicola Smania, A. P. (2012). Rehabilitation of brachial plexus injuries in adults and children. European journal of physical and rehabilitation medicine.

[15] Park, B., Flowerday, T., \& Brünken, R. (2015). Cognitive and affective effects of seductive details in multimedia learning. Computers in Human Behavior, 44, 267-278. doi:10.1016/j.chb.2014.10.061

[16] Pérez-Samaniego, V., Fuentes-Miguel, J., Pereira-García, S., López-Cañada, E., \& Devís-Devís, J. (2018). Experiences of trans persons in physical activity and sport: A qualitative meta-synthesis. Sport Management Review. doi:10.1016/j.smr.2018.08.002

[17] Raikes, A. C., Athey, A., Alfonso-Miller, P., Killgore, W. D. S., \& Grandner, M. A. (2019). Insomnia and daytime sleepiness: risk factors for sports-related concussion. Sleep Med, 58, 66-74. doi:10.1016/j.sleep.2019.03.008

[18] Stares, J., Dawson, B., Peeling, P., Drew, M., Heasman, J., Rogalski, B., \& Colby, M. (2018). How much is enough in rehabilitation? High running workloads following lower limb muscle injury delay return to play but protect against subsequent injury. J Sci Med Sport, 21(10), 1019-1024. doi:10.1016/j.jsams.2018.03.012

[19] Stefani, R. T. (2019). A WORLD OF SPORTS AND RATING SYSTEMS.

[20] Timpka, T., Jacobsson, J., Ekberg, J., Finch, C. F., Bichenbach, J. Edouard, P., . . . Alonso, J. M. (2015). Meta-narrative analysis of sports injury reporting practices based on the Injury Definitions Concept Framework (IDCF): A review of consensus statements and epidemiological studies in athletics (track and field). J Sci Med Sport, 18(6), 643-650. doi:10.1016/j.jsams.2014.11.393

[21] Torre, O. M., Evashwick-Rogler, T. W., Nasser, P., \& Iatridis, J. C. (2019). Biomechanical test protocols to detect minor injury effects in intervertebral discs. J Mech Behav Biomed Mater, 95, 13-20. doi:10.1016/j.jmbbm.2019.03.024

[22] Vergeer, I. (2006). Exploring the mental representation of athletic injury: A longitudinal case study. Psychology of Sport and Exercise, 7(1), 99-114. doi:10.1016/j.psychsport.2005.07.003

\section{AUTHORS PROFILE}

My. Name is Suriani Sari, I am working in Universitas Negeri Jakarta, Indonesia and my area of research is management

I am Moch.Asmawi, I am associated with Universitas Negeri Jakarta, Indonesia. My area of interest is management.

I am James Tangkudung, and I am attached with Universitas Negeri Jakarta, Indonesia. My area of interest is management

My name is Achmad Sofyan Hanif, IKIP PGRI Pontianak. My area of interest is management

I am Firmasyah Dlis, I am associated with IKIP PGRI Pontianak. 